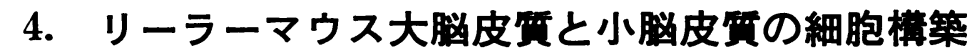

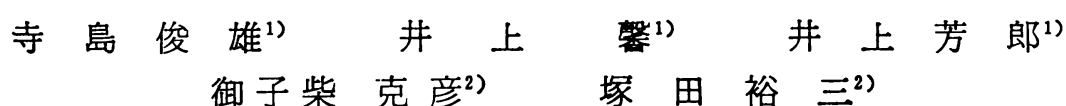

$$
\begin{aligned}
& \text { 北海道大学医学部 解剖学第一講座 }{ }^{1)} \\
& \text { 慶応義熱大学医学部 生理 }{ }^{2)}
\end{aligned}
$$

\section{Cytoarchitecture of Cerebral and Cerebellar Cortices of the Reeler Mouse}

\author{
Toshio TERASHIMA, ${ }^{1}$ Kaoru INOUE, ${ }^{1)}$ Yoshiro INOUE, ${ }^{1)}$ \\ Katsuhiko MIKOSHIBA ${ }^{2)}$ and Yasuzo TSUKADA ${ }^{2)}$ \\ Department of Anatomy, Hokkaido University School of Medicine, Hokkaido' \\ Department of Physiology, School of Medicine, Keio University, Tokyo ${ }^{2)}$
}

\begin{abstract}
Summary
Homozygous reeler mice have action tremor, dystonic posture, and reeling atxic gait. The mutation at the reeler genetic locus (gene symbol: $r l$ ) causes cytoarchitectonic abnormalities to the cerebral and cerebellar cortices. Retrograde transport of horseradish peroxidase (HRP) was used to examine the cells of origin of the corticospinal tract (CST) and the callosal commissural fibers (CC) in the primary motor cortex of normal and reeler mice. In normal controls, CST neurons retrogradely labelled after HRP injection into the lumbar cord were situated only in layer V. In the reeler, by contrast, the labelled CST neurons were scattered difusely all levels of the corresponding cortical area. In addition to the malpositioning of the somata, the labelled CST neurons in the cortex of the reeler could be divided into two major classes according to their dendritic pattern; typical pyramidal neurons and atypical ones. The typical pyramidal neuron had an atypical dendrite projecting from the superior pole of the soma and ascending toward the pia mater. The atypical pyramidal neurons consisted of six types: inverted, tumbled, bipolar, V-shaped, hook-shaped, and superficial polymorphic. The typical pyramidal neurons in the reeler tend to be situated relatively deep in the cortex and the atypical neurons tend to lie relatively superficially in the cortex.

In the normal mouse, CC neurons retrogradely labelled after the injection of HRP into the primary motor cortex are distributed in a bilaminar pattern such that the largest number of cells are located in supragranular layers II and III and infragranular layer V. In the reeler mutant, CC neurons are found in all cortical layers, but two-thirds are situated in the lower half of the cortex. On the basis of the cell shape and orientation of the apical dendrite, $\mathrm{CC}$ neurons of the reeler are classified into six morphological types: typical pyramidal, inverted pyramidal, tumbled, hook-shaped, polymorphic, and simple. The apical dendrites of the CC neurons in all layers of the cortex of the reeler mouse are randomly oriented: no direct relationship between the intracortical position of the soma and orientation of the apical dendrite was found. In contrast, CST neurons in the reeler mutant are concentrated in the outer third of the cortex, and there is a relationship between the laminar distribution of these cells and the alignment of their dendrites with respect to the pial surface: the apical dendrites of CST neurons lie in superficial layers tend to be oriented obliquely, whereas those of CST neurons lie in the deeper cortex most often are oriented vertically, i.e., toward the pial surface. Quantitative analysis revealed that the relative intracortical positions of the CST and CC neurons are reversed in the reeler mutant although both populations exhibited greater laminar disposition, and as a consequence, there is more intermingling of the two cell groups in the reeler than in the normal mouse. Thus, the present study suggests that the normal cytoarchitectonics of the primary motor cortex are inverted in the reeler mutant mouse.
\end{abstract}


Cerebella of the normal and reeler mutant mice at two months of age were studied by the Golgi impregnation method to elucidate the detailed configurations of the Golgi epithelial cells. On the basis of configuration of their Bergmann fibers, the Golgi epithelial cells of the reeler were relatively normal, or assumed inverted, swan neck, stellate, bipolar, small, or fan shapes, although their morphological changes were continuous rather than abrupt. A relatively normal type of Golgi epithelial cells which somewhat resemble those of normal controls was present in the reeler, although some differences between them in detailed appearance existed. It is important to note that the radially organized Bergmann fibers ascending from the somata of this type of Golgi epithelial cells gave rise to a glial architecture of normal appearance in small areas of the cerebellar molecular layer in this mutant. Since the primary action and target cells of the reeler gene have not yet been identified, the question of why the Golgi epithelial cells of the reeler assume such various forms remains unsolved.

\section{緒 曹}

リーラーマウスは中权神経系のらち大脳皮質 ${ }^{11}$, 小 脳皮質 ${ }^{2,3)}$, 海馬 ${ }^{4)}$, 蝸牛神経核背側核 ${ }^{5)}$ な゙皮質構造を 有する部位の細胞構築に著しい異常を認める. また非 皮質構造たとえば視床や脳幹の神経核には異常がない

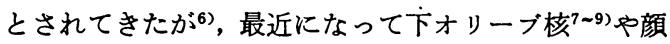
面神経核 ${ }^{10)}$ にも異常のあることがわかり，おそらく中 权神経系の寸べての領域に異常があると思われる.こ のよらな細胞構築の異常は神経芽細胞の細胞移動の障 害に原因を求めることができるが，そのメカニズムの 詳細は判明していない. リーラーマウスの病因の本態 を解明する上で，大脳皮質や小脳皮質などの細胞構築 を詳しく分析することがまず求められるが，いまだに 解明されていない難問が数多く存在している. 著者ら の研究グループは, 括もに西洋ワサビ過酸化酵素 (horseradish peroxidase; HRP) の軸索内逆行性輸 送法を利用した伝導路学の面から本奇形マウスの皮質 脊蹃路 (corticospinal tract; CST) ニューロン, 脳 梁交連線維系 (callosal commissural fibers; CC) = ュ一ロンの大脳皮質内分布を分析し，また鍍銀法によ り小脳皮質内にあるゴルジ上皮細胞の形態を研究して きた ${ }^{11 \sim 13)}$. 本稿ではおもに著者らの研究成果について 紹介するが，リーラーマウスの全体像を掌握するため には引用文献中の総説を参考にして欲しい14 19).

\section{実験動物と方法}

実験動物は 2,3 カ月龄の正常マウス (BALB/c 系) とリーラー遺伝子 (遺伝子記号; $r l$ ) を $\mathrm{BALB} / \mathrm{c}$ 系マ ウスに導入したリーラー奇形マウスである.

1） HRP 組織化学：ネンブタール腹腔内投与によ り実験動物を麻酔し, 脳定位固定装置に固定した. 上 部腰㵦あるいは左側運動野下肢領域に HRP を注入 し，48時間後にエーテル麻酔下でグルタールアルデヒ ドとパラホルムアルデヒドの混合液で灌流屠殺した.
HRP の組織化学的反応方法は LaVail $5^{20)}$ の方法に 準じた.

2）定量的方法（Fig.1）：CST 系と CC 系ニュー ロンの皮質内分布および頂上樹状突起の方向を数量的 に比較するために次のような定量化を図った。 まず標 識ニューロンの皮質内位置は Fig. 1®で図示したご とく定めた. 大脳皮質の表面に沿って任意の切線を引 く. 次にこの切線に垂直な法線のうち標識ニューロン の細胞体の中心（\$）を通るものを選ぶ. こうして得 られた法線が軟膜と白質を横切る点をそれぞれ A， B と定めた. ここで線分 B(S) の長さをるって標識ニュ 一ロンの皮質内位置とするのは不適当である.すなわ ち, 大脳皮質の厚さはある狭い領域内でも変化するの で，たんに B@の長さを比較したのでは皮質の厚さ （AB）の異なる領域間で標識ニューロンの皮質内位置 を数量的に比較することができない，そこで線分 B(S) の ABに対する百分比をもって標識ニューロンの相対 的皮質内位置としこれをZで表した. 次に頂上樹状突 起の方向は Fig. 1(B) のように定めた. 頂上樹状突起 が細胞体より分岐する位膡をＯと定め，Oを中心とし て半径 $100 \mu \mathrm{m}$ の円をュンパスで描く. この円と頂上 樹状突起の交点を $\mathrm{R}$ とする. 前に定めた $\mathrm{AB}$ と平行に $\mathrm{OP}$ を引 $\mathrm{OP}$ と $\mathrm{OR}$ のなす角 $(\angle \mathrm{POR} ; \theta)$ をむっ て頂上樹状突起の方向を定義した. リーラーマウスの CST 系や CC 系のニューロンには後述するように頂 上樹状突起に似た突起を 2 本もつことがあり, との突 起が頂上樹状突起であるか定められない場合がある. このときはおのおのの頂上樹状突起様突起について独 立に角度を計測した（たとえば Fig.1D).

3）鍍銀法 : 実験動物をエーテル麻酔下で断頭し, ただちに大脳と小脳を Stensaas によるゴルジ変法21) に順じて鍍銀した．組織片は上昇フルコール系列にて 脱水後,アセトンで置換し,セロイシンに浸漬し，70\% 

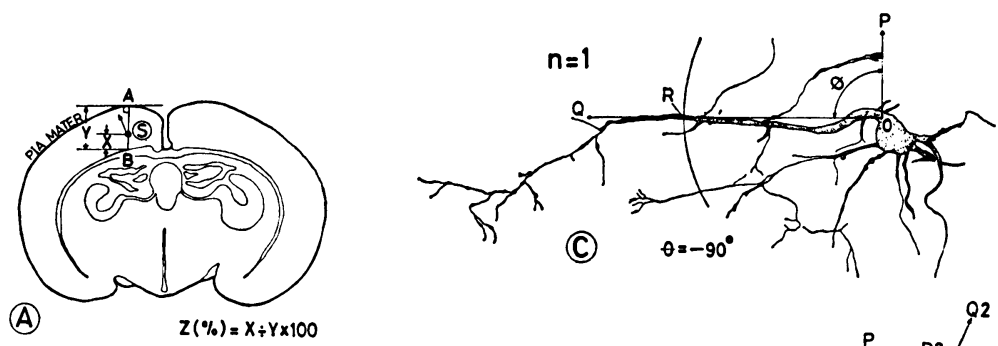

(A)
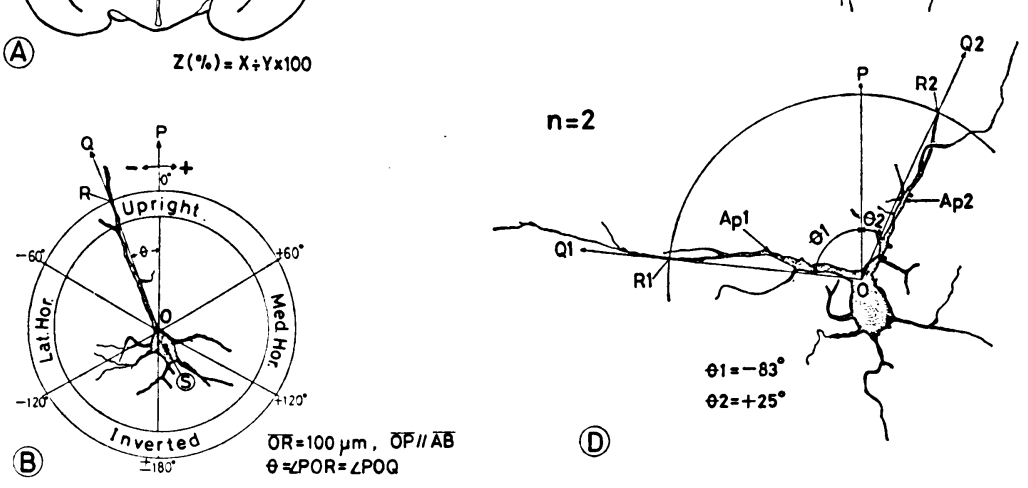

Fig.1. Quantitative procedures for determining the intracortical position of labelled neurons and the orientation of their apical dendrite. The standardized intracortical position ( $Z$ ) of a labelled neuron and the direction of its apical dendrite $(\theta)$ are measured as shown in A and B, respectively. If the labelled neuron has only one apical dendrite $(n=1)$, the direction of the apical dendrite is measured as illustrated in C. If the labelled neuron has two apical-like dendrites $(n=2)$, the directions of these apical-like dendrites are measured separately, as illustrated in D (Ref. 12)).

アルコールにて硬化させ, $100 \mu \mathrm{m}$ 厚に薄切した.

\section{結果と考腺}

\section{1）大脳皮質の反転構造}

リーラーマウスの大脳皮質には正常マウスの大脳皮 質の第 1 層（分子層）が存在しない。またオートラジ オタラフィーによる発生学的な研究により層構造が逆 転しているといわれている222.このような大脳皮質の 逆転構造が正しいとするならば正常マウスの第 5 層 （大錐体細胞層；LP）はリーラーマウスでは表層より 数えて第 2 層の大錐体細胞層 (LP) に対応することに なる (Fig.2).したがって, 第 5 層に限局して存在す る CST =ューロンは, リーラーマウスでは LP 層に 限局して存在することになる.この推測を検証するた めに HRP を上部腰酭に注入し, 標識 CST ニューロ ンを比較した．標識ニューロンは正常マウスとリーラ 一マウスともに大脳皮質運動野の下肢領域 ${ }^{23}$ に一致し て存在した(Fig.3). 運動野以外では, 視覚野もその存 在部位が正常マウスとリーラーマウス間で差がないこ とがすでに明らかにされている2428).この事実はきわ めて基本的なもので重要である. すなわち, 細胞構筑
の異常にもかかわらず，正常マウスの大脳皮質上の機 能局在はリーラーマウスの大㜆皮質においても正確に 再現されていることを意味するからである. 換言する ならば, リーラーマウスの神経芽細胞の移動障害は軟 膜に対して垂直方向のみであり, 接線方向の移動障害 はないと思われる。

次に CST 系ニニーロンの皮質内分布をみてみると 正常マウスでは第 5 層 (LP) に限局しているが, リー ラーマウスでは予測と異なり LP 層に限局せず，皮質 の全層に標識ニューロンが分布した（Fig.4）．したが ってリーラーマウスの皮質の構造は従来より提言され ている反転構造ではないと思われる. 翻って考えてみ ると,リーラーマウスの大脳皮質の各層の境界を定め ることは非常にむずかしいが29,30)，その一因として $\mathrm{LP}$ 層の大型錐体細胞（ここでは CST ニニーロン） のように, 各層の構成細胞が層の境界を越えて広く分 布することが挙げられよう。このことは鍍銀法により 大型錐体細胞は LP 層ばかりではなく，皮質の深層 (MP+SP 層) にも存在するといら報告に一致する ${ }^{31)}$. それではリーラーマウスの大脳皮質の逆転構造は誤 


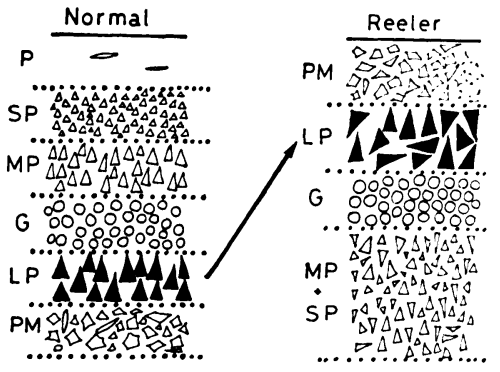

Fig.2. Schematic representation of the distribution of basic neuronal classes in normal neocortex and in corresponding cortical areas of the reeler mouse. The left column displays the normal positions of plexiform layer $(\mathrm{P})$; layer of small pyramids (SP) ; layer of medium pyramids (MP) ; layer of granule cells (G) ; layer of large pyramids (LP); and layer of polymorphic cells (PM). The right column shows the relative distributions of the homologous classes of neurons in the corresponding cortical area in the reeler mouse. Note the absence of plexiform layer and reversal of position of cell classes. The corticospinal tract (CST) neurons are shaded.
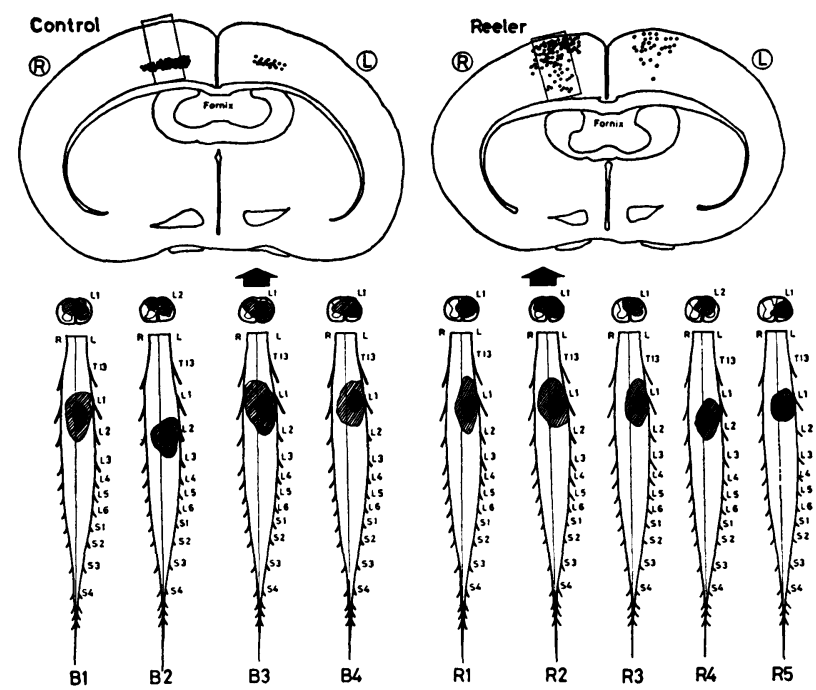

Fig.3. Schematic illustrations of the injection sites of HRP into the upper lumbar cord of normal (B1-B4) and reeler mutant mice (R1-R5), and the distribution pattern of HRPlabelled neurons in the primary motor cortex (dots). The labelled CST neurons are situated in the corresponding cortical areas of normal and reeler mice. The rectangles on the right cerebral cortices of normal and reeler mice are also illustrated in Fig. 4A and B (Ref. 11)).
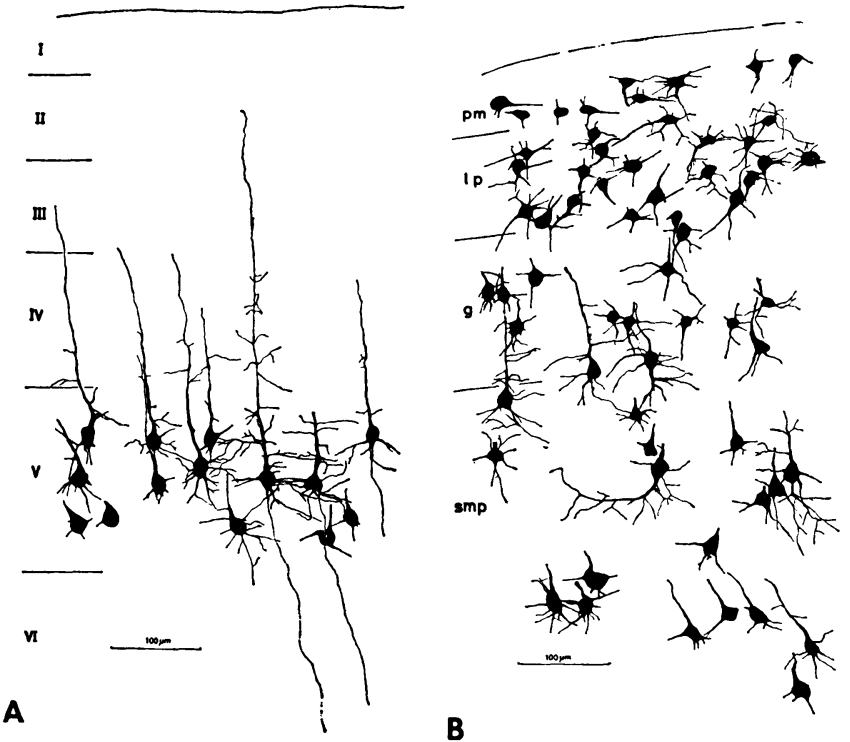

Fig.4. Schematic illustrations of HRP-labelled CST neurons in the motor cortex of the normal (A) and reeler (B) mice (Ref. 11)). 


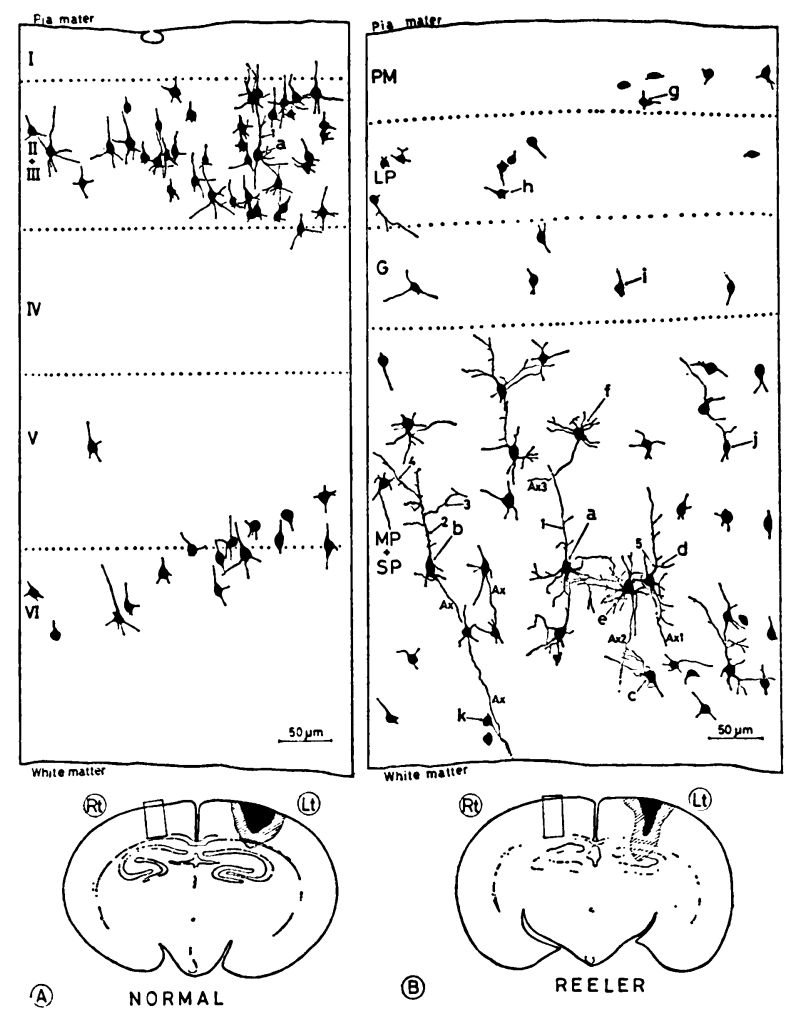

Fig.5. Drawings of HRP-labelled callosal commissural (CC) neurons of normal (A) and reeler (B) mice. In the normal mouse (A), the labelled pyramidal neurons (e.g., cell a) are concentrated in layers II and III. In the reeler (B), the labelled neurons are scattered in all zones of the cortex. Typical pyramidal (cells a and b), inverted pyramidal (cell c), hook-shaped (cell d), polymorphic (cells e and $\mathrm{f}$ ), and simple (cells $\mathrm{g}-\mathrm{k}$ ) type neurons are labelled by HRP (Ref. 12)).
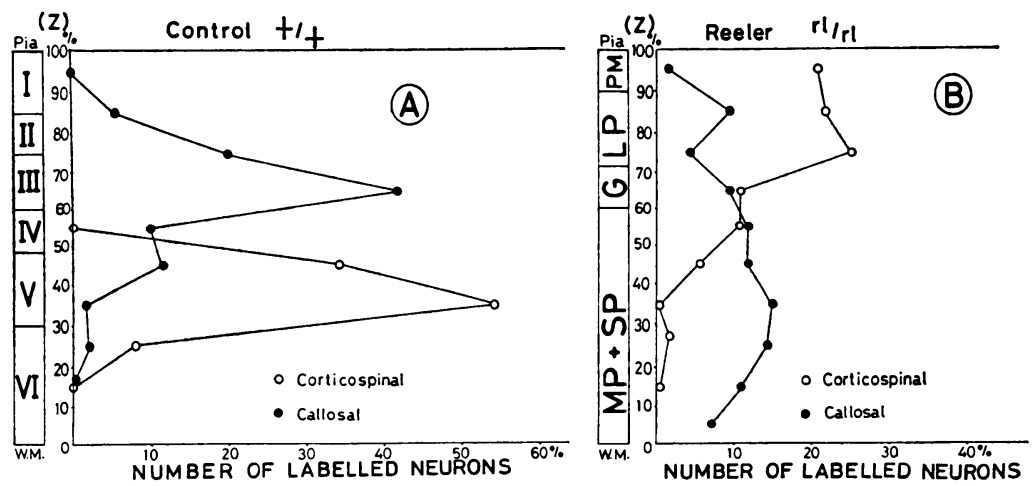

Fig. 6. Distribution patterns of CST and CC neurons in normal (A) and reeler (B) mice (Ref. 12)). 
りであろらか. 著者らはCST と CC 系ニューロンの 皮質内分布を定量的に比較することによりさらに逆転 構造説を検証した。この 2 系を選んだ理由は正常マウ スの CST ニューロンは 5 層に限局すること，また CC ニューロンは皮質の 2 6 層に広く分布するが，おす に2 層 (SP) 深部と 3 層 (MP) に限局することなど により正常マウスとリーラーマウス間の層構造の対応 づけをしやすいといら推測に基ついている．実験の結 果, 正常マウスでは CST =ューロンは 5 層に例外な く限局し， CC ニューロンの約 $70 \%$ はII層深部と III 層に存在した (Fig. 4A，5(A，6(A)). 他方リーラーマ ウスでは CST, CC ニューロンともに皮質内に広く 分布するが, 最も密度が高く分布するのは CST 系が $\mathrm{LP}$ 層, CC 系が $\mathrm{MP}+\mathrm{SP}$ 層であった (Fig.4B, 5B, 6()．したがってCST ニューロンと CC ニューロン の最も多く存在する層の相対的深度はリーラーマウス では逆転することになる（Fig. 6). 結局，CST 系と $\mathrm{CC}$ 系の皮質内分布といら観点からみると，リーラー マウスの大脳皮質は逆転構造を呈すると結 論できる

(Fig. 7). たたし，前述したようにリーラーマウスで
は層を構成するニューロンがより広く分布することに より, 従来より呈示されていた単純な逆転構造ではな いことは明らかである.

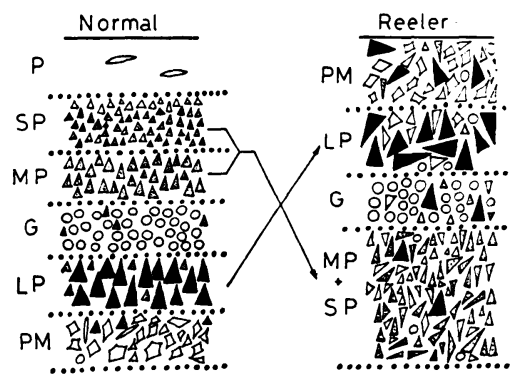

Fig.7. Schematic representation of the distribution of the basic neuronal classes in normal and reeler neocortices. The distribution pattern of CST (shaded) and CC (hatched) neurons indicate that, although there is more intermingling of the two cell groups in the reeler than in the normal mouse the relative intracortical positions of CST and CC neurons are reversed in the reeler mutant.
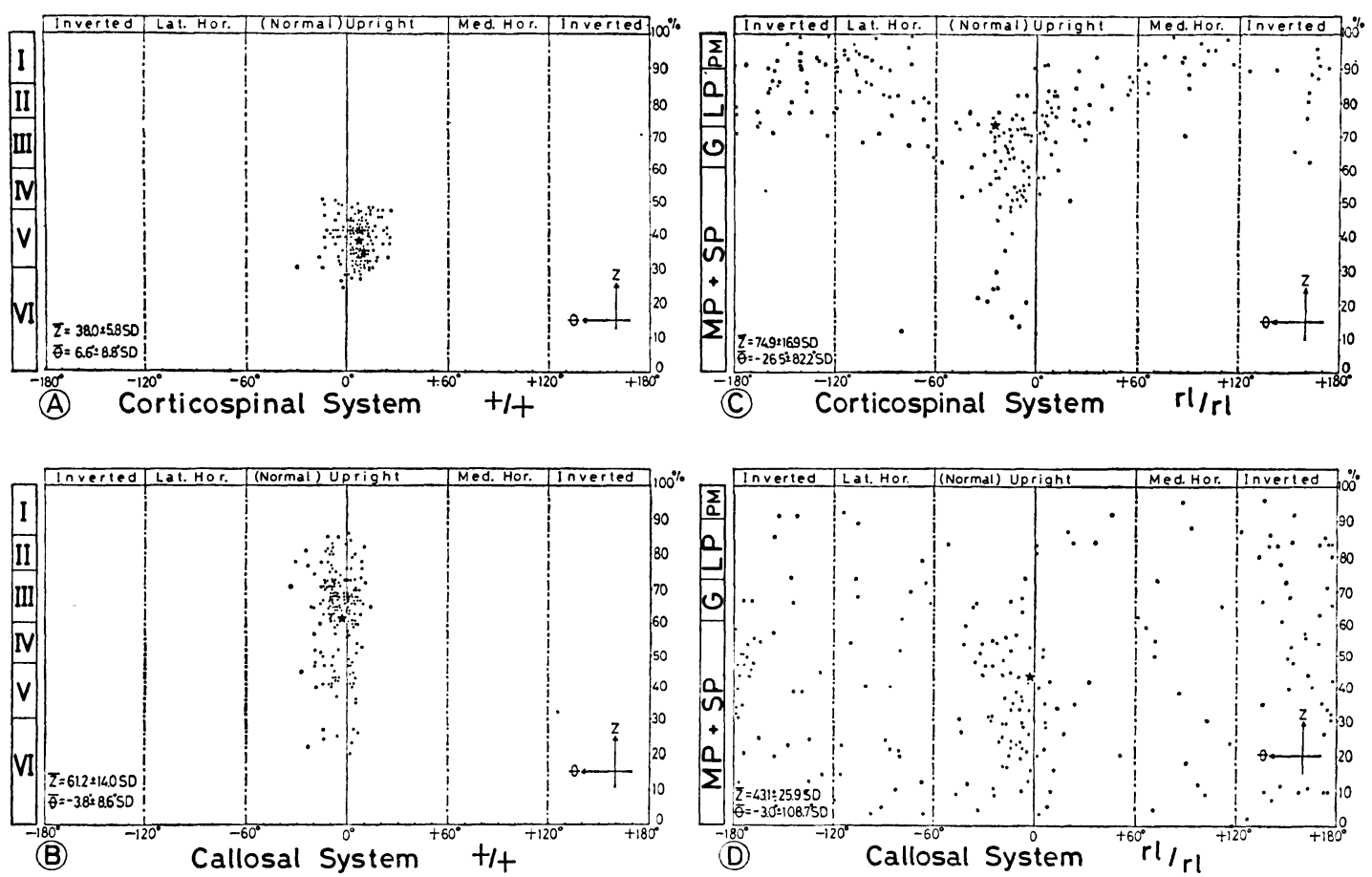

Fig. 8. Two-dimensional diagrams representing the standardized intracortical position (Z) of the CST and $\mathrm{CC}$ neurons and the angular displacement of their apical dendrites $(\theta)$ in normal and reeler mice. The positions of the star in (A)-(D) represent mean values of $Z$ and $\theta$ (Ref. 12)). 


\section{2）樹状突起の形態}

おもに鍍銀法によりリーラーマウスの大脳皮質には 多様な形態を呈するニューロンがあることが知られて いる ${ }^{29,31,32)}$. 著者らの HRP 法の研究の結果, 鍍銀法 で証明された形態と類似する CST, CC ニューロンを 観察することがでさた. たとえば, 頂上樹状突起の数 と形態より CST 系では正常錐体型, 反転型, 横転型, 双極型， V字型，鈞型，表層多形型などに分類され (Fig.4B)，CC 系は正常錐体型, 反転型, 横転型, 鉤 型, 多形型, 単純型などに分類された (Fig.5(B). 同 一の伝導路系に属しながらニューロンの形態が異なる といらことは, ニューロンの形態が必ずしす一義的に 遺伝により决定されるすのではなく, 発生・発育過程 で周囲の微小環境により影整をこうむる性質であるこ とを示している. それではニューロンの樹状突起の形 態決定因子としてニューロン周囲の微小環境の実体は 何であろらか. ここで興味ある事実は細胞体の位置 (Z) と頂上樹状突起の方向 $(\theta)$ との間の相関である. リーラーの CST ニューロンを例にとると，大譄皮質 の深層（Zの值が0に近い）にある標識ニューロンは 正常錐体型，すなわち頂上樹状突起の方向は軟膜にむ からが $\left(|\theta|<60^{\circ}\right)$ ，皮質の浅層（Zが 1 に近い）にあ る標識 ニニーロンは異常錐体型, すなわち頂上樹状突 起は水平あるいは下方にむから $\left(60^{\circ}<|\theta|<180^{\circ}\right)$ (Fig. 8C). 端的にいうと皮質内深度に依存して樹状 突起の形態が変化するのである. すちろん=ューロン 自身が皮質内深度 $(Z)$ そのものを情報として感知し Zに応して樹状突起の形態を変化させるとは考えにく い.おそらく Zと連関して変化する何かが形態変化を 起こす原因であろう．最近，頂上樹状突起は樹状突起 に対する入力線維の方向に発育するといら興味ある仮 説が提示された ${ }^{31,33)}$. もしこの仮説が正しく，しかも 入力線維層が皮質の中層にあれば，この線䧽層より深 層に細胞体をむつニューロンの頂上樹状突起は上方に 伸び正常錐体型となり, 同層より浅層に細胞体のある ニューロンの頂上樹状突起は下方に伸び反転型となる であろう．入力線維層がZと連関するのは明白である から，このような仮説は CST ニューロンの頂上樹状 突起の形態形成を考えるらえで無視できない.

一方, リーラー CC ニューロンは皮質の全層におい て正常錐体型と異常錐体型が共存することにおいて $\mathrm{CST}$ ニューロンとは著しい対照をなす (Fig. 8D). 換言すると, リーラー CC ニューロンの皮質内位置 （Z）と頂上樹状突起の方向 $(\theta)$ の間に何ら相関を認
めない，顆粒細胞をX線を照射することにより殺し， プルキンエ細胞に対する入力を人為的になくすと，プ ルキンエ細胞の樹状突起は自動性を発揮し，無規則な 方向に伸長することが知られている34).これと似たよ

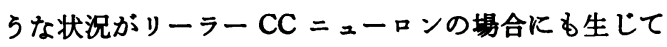
いるのであろらか. いずれにしてる皮質内位膡と頂上 樹状突起の方向に相関をみとめる系 (リーラーCST) と琾めない系（リーラーＣC）の二つを得たことは， 樹状突起の形態形成の理論を検証する系をわれわれが 得たことになるので意義深い。

3）ゴルジ上皮細胞

小脳皮質は三層構造を有し，しかも各層に分布する グリア細胞は層特有の形態を呈する ${ }^{35)}$. リーラーマウ スの小脳皮質は異常なので36)，グリフ細胞にも異常形 態が出現すると思われる．本稿では小脳分子層にあり 特異な形態と配列を示すゴルジ上皮細胞について論じ る (Fig.9, GE1-5).

さてリーラーマウスのゴルジ上皮細胞はその形態が 正常に近いものから極端な異常型に至るまで多様な形 態を呈し，しかもその形態変化は連続的なので分類す ることが困難であるが，著者らは説明の便宜上，比較 的正常型と異常型に二大別し，さらに後者を反転型， 双極型, 白鳥の首型, 星型, 扇型, 小型等の亜型に細別 した. 比較的正常型は対照マウスのゴルシ上皮細胞に 著しく形態が類似する（Fig.10；GE1 と GE2）. 文献 的にはリーラーマウスのゴルジ上皮細胞のハーーグマン 線稚の方向は無規則で分子層内を櫛状に配列するもの はないというすのと ${ }^{37)}$ ，ある小部分に限り正常に配列

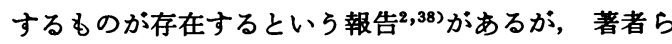
の所見は後者を支持するすのである．ただ，「比較 的」正常型といら名称から推測できるよらに，まった く正常であるとはいえない，たとえばバーグマン線稚 の尖端は軟膜に達せず，グリア境界膜を形成しない等 である. 次に異常型ゴルジ上皮細胞について述べる が，すべてを記載する余裕がないので反転型のみ紹介 する (Fig.10, GE3). 細胞体が軟膜直下にあり, 細胞 体の下面より太い下行幹が深層にむかって伸び (DS)， 細胞体の側面あるいは下行幹より数条のバーグマン線 維が分子層中を軟膜に平行に走る $(\mathrm{P} 1 \sim \mathrm{P} 7)$. これら の線維には䚬片状や結節状の突起が付着し, またその 尖端がシート状に広がり血管を包むこと（Fo）などか ら, 全体としての形態は異常であるが正常バーグマン 線維の性質をよく保存しているといえる.このような ゴルジ上皮細胞の異常により小脳皮質の構築が乱れる 


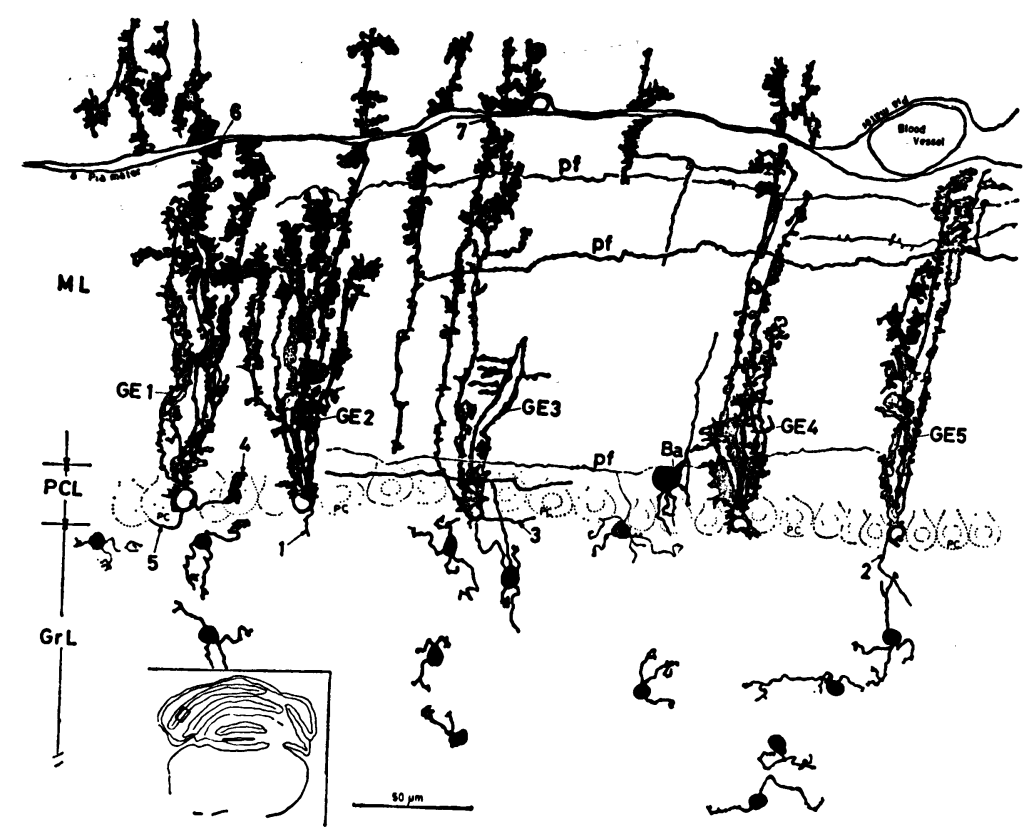

Fig.9. Illustration of five Golgi epithelial cells (GE1-5) of the normal BALB/c mouse. The slender perikaryal processes issue from the lower or lateral surfaces of their somata (arrows 1-5). The Bergmann fibers end in conical swellings or nodal protuberances just beneath the pia mater, constituting the glial limiting membrane (arrows 6 and 7). Abbreviations: Ax, axon; GE, Golgi epithelial cells; Gr, granule cells; GrL, granular layer; ML, molecular layer; PC, Purkinje cell layer; pf, parallel fiber (Ref. 13)).

のか, あるいは小脳構筑が乱れたためにゴルジ上皮細 胞に異常が生じるのか，その因果関係は不明である。

\section{展望}

この章では, 疾患モデル動物としてのリーラーマウ スの利用法について述へてみたい。リーラーマウスは 神経芽細胞の移動障害を特徵とするが，ヒトで神経芽 細胞の移動障害を特徵とする先天性疾患には無脳回, 厚脳回，小多回脳，孔脳症などがある. したがってリ ーラーマウスの病態を究明すれば，上記の重篤な先天 性奇形の原因が明らかになるであろう。

このよらな医学的側面から利用する以外に, リーラ 一マウスは神経生物学上の困難な問題を解决する上で まさに天与の実験動物であり，下記に列記するごとく 多数の利用法が考兄られる.

1）リーラーマウスでは，ニューロンが異常位置に あっても，あるいは標的ニューロンが異常位直にあっ ても，正しくシナプス結合を形成する．したがって化 学親和説などの神経回路網の形成理論を検証できる.

2）神経芽細胞の移動は放射状クリア線維 （radial glial fiber; RGF) に誘導されるという説尔とマとトリ ックス細胞の脚の束 ${ }^{(2)}$ 亿誘導されるといら説 ${ }^{40,41)}$ が鋭 く対立している、リーラーマウスは神経芽細胞の移動 障害があるので, リーラー遺伝子座 $(\boldsymbol{r} l)$ の一次標的 を定めることができれば，この論争を解決できるであ ろら.

3） =ューロンの形態，とくに樹状突起の形態が何 により規定されるか，とくに入力線稚により支配され るといら説を含めて解明できる.

4）小脳皮質の三次元立体構築の形成に最も先導的 役割を果たす構造は，バークマン線維であるという 説 42) と平行線維であるとする説“3) があり一致をみな い.リーラーマウスの小脳皮質には比較的正常に保た れる部分と皮質構造をまったく呈しない部分があり， 小脳皮質の形成に関する仮説を検証できる.

5）皮質構造と非皮質構造では神経芽細胞の移動の 形式がことなる.すなわち, 皮質構造では, 先に移動し た神経芽細胞を後に移動を開始したるのが乗り越えて いくが (inside-out pattern), 非皮質構造ではたんK 


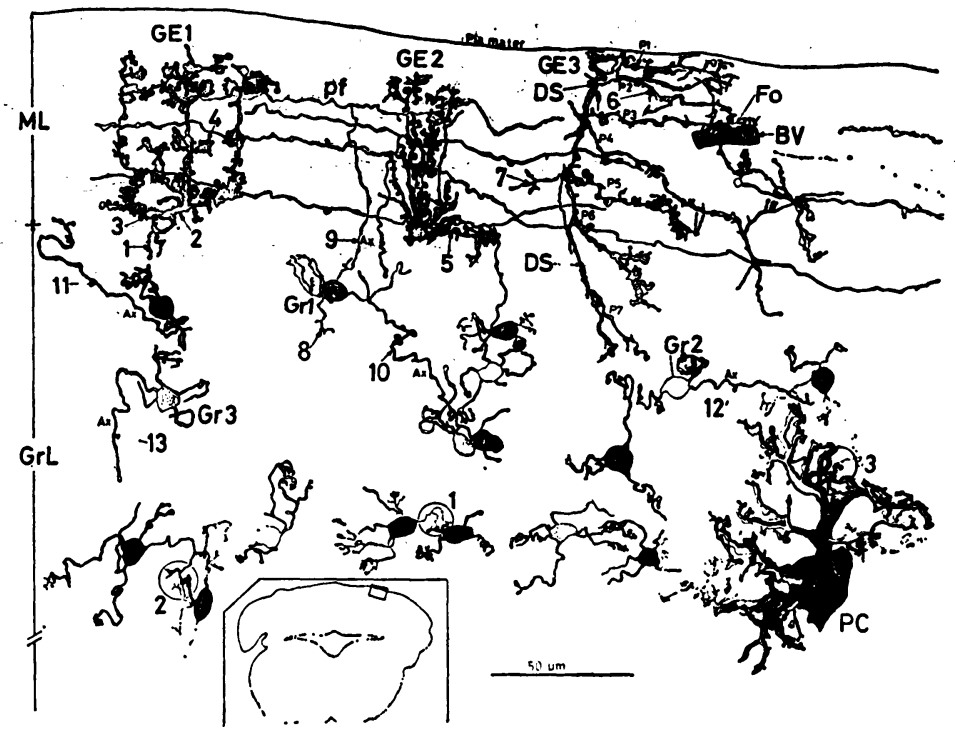

Fig.10. Illustration of three Golgi epithelial cells, two of relatively normal type (GE1 and 2) and one which is inverted (GE 3) in the reeler mouse. The slender descending perikaryal process of GE1 is shown by arrow 1. Two horizontally directed glial processes (arrows 2 and 3 ) and one horizontally directed Bergmann fiber (arrow 5) separate, respectively, from the somata of GE1 and 2. Leaf-like appendages expand from radially aligned Bergmann fibers (arrow 4). From the same side of the soma and the main descending stem (DS) of the inverted Golgi epithelial cell (GE3), seven glial processes (P1-7) with secondary branches (arrow 6) advance horizontally or inferiolaterally. These secondary branches ensheath a blood vessel (BV) with their perivascular feet (Fo). A few short glial processes arose from one side of the DS (arrow 7) (Ref. 13)).

樻み重なるだけである (outside-in pattern). リーラ 一マウスの皮質構造の細胞構築は大きく崩れるが, 非 皮質構造には大きな異常は認められない. したがっ て，本マウスの皮質構造と非皮質構造の各領域におけ る神経芽細胞の移動を研究することにより,なぜ両領 城の間で細胞移動の形式が異なるか判明するたろう。

\section{文献}

1) Mikoshiba, K., Kohsaka, S., Takamatsu, K., Aoki, E. and Tsukada, Y. : J. Neurochem., 34, 835 (1980)

2) Mikoshiba, K., Nagaike, K., Kohsaka, S., Takamatsu, K., Aoki, E. and Tsukada, Y.: Dev. Biol., 79, 64 (1980)

3) Sekiguchi, M. : Keio Igaku, 60, 259 (1983) (in Japanese)

4) Terada, S., Shimai, K., Mikoshiba, K. and Tsukada, Y.: Dev. Brain Res., 11, 219 (1983)
5) Martin, M.R. : J. Comp. Neurol., 197, 141 (1981)

6) Terashima, T., Inoue, K., Inoue, Y., Mikoshiba, K. and Tsukada, Y. : J. Comp. Neurol., 225, 95 (1984)

7) Goffinet, A.M. : J. Comp. Neurol., 219, 10 (1983)

8) Goffinet, A.M., So, K.-F., Yamamoto, M., Edwards, M. and Caviness, V.S., Jr. : Dev. Brain Res., 16, 263 (1984)

9) Hashikawa, T., Kawamura, K., Mikoshiba, K. and Tsukada, Y. : Neurosci. Lett. Suppl., 17, S21 (1984)

10) Goffinet, A.M. : J. Anat., 138, 207 (1984)

11) Terashima, T., Inoue, Y., Mikoshiba, K. and Tsukada, Y.:J. Comp. Neurol., 218, 314 (1983)

12) Terashima, T., Inoue, K., Inoue, Y., Mikoshiba, K. and Tsukada, Y. : J. Comp. Neurol., 232, 83 (1985)

13) Terashima, T., Inoue, $K .$, Inoue, $Y .$, Miko- 
shiba, K. and Tsukada, Y. : Dev. Brain Res., 18, 95 (1985)

14) Mikoshiba, K. : Igaku No Ayumi, 117, 445 (1981) (in Japanese)

15) Mikoshiba, K. : Shinkei Shinpo, 23, 918 (1979) (in Japanese)

16) Mikoshiba, K., Okano, H. and Tsukada, Y. : Protein, Nucleic Acid and Enzyme, 29, 1633 (1984) (in Japanese)

17) Caviness, V.S., Jr. and Rakic, P. : Ann. Rev. Neurosci., 1, 297 (1978)

18) Caviness, V.S., Jr., Pinto-Lord, M.C. and Evard, P. : Morphogenesis and Pattern Formation (Connelly, T.G., ed.), Raven Press, New York, pp. 103-126 (1981)

19) Goffinet, A.M. : Brain Res. Rev., 7, 261 (1984)

20) LaVail, J.H., Winstone, K.R. and Tish, A. : Brain Res., 58, 470 (1973)

21) Stensaas, L.J. and Stensaas, S.S. : Z. Zellforsch., 84, 473 (1968)

22) Caviness, V.S., Jr. and Sidman, R.L. : J. Comp. Neurol., 148, 141 (1973)

23) Hall, R.D. and Lindholm, E.P. : Brain Res., 66, 23 (1974)

24) Dräger, U. : J. Comp. Neurol., 201, 555 (1981)

25) Lemmon, V. and Pearlman, A.L. : J. Neurosci., 1, 83 (1981)

26) Simmons, P.A. and Pearlman, A.L. : Dev. Brain Res., 4, 124 (1982)

27) Simmons, P.A., Lemmon, V. and Pearlman, A.L. : J. Comp. Neurol., 211, 295 (1982)

28) Simmons, P.A. and Pearlman, A.L. : J.
Neurophysiol., 50, 838 (1983)

29) Caviness, V.S., Jr. : Exp. Brain Res., Suppl. 1, 267 (1976)

30) Caviness, V.S., Jr. : Dev. Brain Res., 4, 293 (1982)

31) Pinto-Lord, M.C. and Caviness, V.S., Jr. : J. Comp. Neurol., 187, 49 (1979)

32) Landrieu, P. and Goffinet, A. : Cell Tissue Res., 218, 293 (1981)

33) Caviness, V.S., Jr. : Trends Neurosci., 3, 31 (1980)

34) Altman, J. and Anderson, W.J. : J. Comp. Neurol., 146, 355 (1972)

35) Palay, S.L. and Chan-Palay, V. : Cerebellar Cortex. Cytology and Organization, SpringerVerlag, Berlin-Heidelberg-New York, pp. 288321 (1974)

36) Mariani, J., Crepel, K., Mikoshiba, K., Changeux, J.P. and Sotelo, C. : Philos. Trans. $R$. Soc. London, 281, 1 (1977)

37) Bignami, A. and Dahl, D. : J. Comp. Neurol., 155, 219 (1974)

38) Ghandour, M.S., Derer, P., Labourdette, G., Delaunoy, J.P. and Langley, O.K. : J. Neurochem., 36, 195 (1981)

39) Rakic, P. : Trends Neurosci., 4, 184 (1981)

40) Hattori, T. and Fujita, S. : J. Electron Microsc., 23, 269 (1974)

41) Fujita, S., Hattori, T., Fushiki, S., Mikoshiba, K. and Tsukada, Y. : Shinkei Shinpo, 26, 433 (1982) (in Japanese)

42) Rakic, P. : J. Comp. Neurol., 141, (2831971)

43) Altman, J. : J. Comp. Neurol., 163, 427 (1975) 